\title{
Effect of Potassium, Magnesium, and Calcium Deficiencies on Nitrogen Constituents and Chloroplast Components in Citrus Leaves
}

\author{
Ruth Lavon \\ Institute of Horticulture, Agricultural Research Organization, The Volcani Center, Bet Dagan, Israel 50250 \\ Raphael Salomon \\ Institute of Plant Protection, Agricultural Research Organization, The Volcani Center, Bet Dagan, Israel 50250 \\ Eliezer E. Goldschmidt \\ The Kennedy-Leigh Centre for Horticultural Research, Faculty of Agriculture, The Hebrew University of \\ Jerusalem, Rehovot, Israel 76100
}

AdDitional INDEX words. amino acids, Citrus volkameriana, leaf chlorosis, nitrate reductase, proline, RuBPcase

\begin{abstract}
The chlorotic appearance of mineral-deficient citrus leaves presumably reflects degradative changes in chloroplast components, most of which have nitrogen as a principal constituent. To examine this assumption the size of some major nitrogen pools, the SDS-PAGE pattern of soluble and chloroplast membranal proteins, and the activities of nitrate reductase and ribulose bisphosphate carboxylase (RuBPcase) were determined in leaves of rough-lemon (Citrus volkameriana Ten. \& Pasq) plants grown hydroponically for 3 to 10 months under $\mathrm{K}, \mathrm{Mg}$, and Ca deficiencies. Plants grown under minerally deficient conditions produced less biomass. Leaves developing under $\mathrm{K}, \mathrm{Mg}$, and Ca-deficient conditions had significantly reduced concentrations of the respective elements. Chlorophyll levels of the chlorotic Mg and Ca-deficient leaves were lower than those of control leaves but chlorophyll a/b ratios were not markedly different. Calcium deficiency caused significant decreases in total nitrogen, nitrates, and the free amino acid pool. Proline which is the major component of the free amino acid pool decreased by $82.5 \%$. Calcium-deficient leaves had significantly lower nitrate reductase and RuBPcase activities. The level of RuBPcase holoenzyme and its subunits were also reduced. Protein levels of $\mathrm{K}, \mathrm{Mg}$, and Ca-deficient leaves were not significantly altered. The SDS-PAGE patterns of soluble and chloroplast membranal proteins did not reveal major qualitative changes. In conclusion, the data do not demonstrate a general close link between chlorosis of minerally deficient citrus leaves and nitrogen metabolism. Calcium deficiency seems to specifically interfere with early stages of nitrogen assimilation and free amino acid accumulation but the metabolic integrity of the leaf is apparently maintained even under severe nutritional stress conditions.
\end{abstract}

Plants suffering from certain mineral deficiencies develop leaf chlorosis symptoms. In citrus, different mineral deficiencies induce distinct chlorosis patterns which might be used as diagnostic tools (Chapman, 1968; Smith, 1966). Chlorosis induced by mineral deficiencies is associated with damage to chloroplast structure, as demonstrated with several plant species by electron microscopy (Hecht-Buchholz, 1979; Thomson and Weier, 1962; Vesk et al., 1966). Thus, the chlorotic appearance of mineral deficient leaves seems to reflect more than just loss of chlorophyll. It most probably involves degradative changes in chloroplast components and additional cellular compartments.

Nitrogen is a major constituent of numerous chloroplast components. A large amount of reduced $\mathrm{N}$ is stored in the RuBPcase protein and in the light-harvesting chlorophyll-protein complexes (Evans and Seemann 1989). RuBPcase, which forms nearly 50\% of the soluble protein of the leaf may account for one-third to onehalf of the total nitrogen in that organ (Lawlor, 1994). Nitrogen is also a constituent of the chlorophyll molecule and the balance between RuBPcase and chlorophyll may be important for maintaining efficient photosynthesis (Osaki et al., 1993). Plants exposed to various stresses, including nutrient stresses, exhibit a loss

Received for publication 1 Apr. 1998. Accepted for publication 28 Sept. 1998. Agricultural Research Organization, the Volcani Center, Bet Dagan, Israel, contribution 2103-E. The technical assistance of S. Shapchiski , E. Mohel, and D. Galili is gratefully acknowledged. We also thank U. Kafkafi and I. Klein for critical reading of the manuscript. The cost of publishing this paper was defrayed in part by the payment of page charges. Under postal regulations, this paper therefore must be hereby marked advertisement solely to indicate this fact. of RuBPcase (Lawlor et al., 1987; Peoples and Koch, 1979). Another biochemical characteristic of plants suffering from nutritional disorders is the accumulation of certain amino acids, amines or ammonia in their leaves (Durzan, 1995; Rabe, 1990; Rabe and Lovatt, 1984). In the present study, we explored the effects of K, $\mathrm{Mg}$, and $\mathrm{Ca}$ deficiencies on the major nitrogenous constituents, protein components and enzyme activities of citrus leaves. The overall objective of the present study was to search for changes in nitrogenous cell and chloroplast components which might be related to the chlorosis syndrome of mineral-deficient citrus leaves.

\section{Material and methods}

Plant material and growth conditions. Uniform rooted cuttings of rough lemon were grown in 10-L buckets, two plants in each. Buckets were arranged in a completely randomized block design, with three replications, and contained modified, aerated Long-Ashton full-nutrient solution and solutions deficient in $\mathrm{K}$, $\mathrm{Mg}$, or Ca as previously described (Lavon et al., 1995). Plants were held in the nutrient solutions for a period of up to 10 months. Mature, fully expanded leaves that had developed at least three months after the transfer to deficient conditions, with visible deficiency symptoms, were used for the various analyses. For the biochemical assays leaves from six plants from each nutritional treatment were pooled. Averages were obtained from several experiments, as indicated in the tables. Samples for growth characteristics, mineral and free amino acid analyses were taken from individual plants, with each plant serving as a replicate. Data from 
Table 1. Biomass production per plant $(n=6)$ in control and mineral-deficient rough-lemon plants. Plants were grown in nutrient solutions for 10 months.

\begin{tabular}{|c|c|c|c|c|c|c|}
\hline \multirow[b]{3}{*}{ Treatment } & \multicolumn{6}{|c|}{ Biomass (g) } \\
\hline & $\begin{array}{l}\text { Initial } \\
\text { fresh }\end{array}$ & $\begin{array}{l}\text { Final } \\
\text { fresh }\end{array}$ & $\begin{array}{c}\text { Final } \\
\text { dry }\end{array}$ & $\begin{array}{c}\text { Leaf } \\
\text { dry }\end{array}$ & $\begin{array}{c}\text { Shoot } \\
\text { dry }\end{array}$ & $\begin{array}{l}\text { Root } \\
\text { dry }\end{array}$ \\
\hline & wt & wt & wt & wt & wt & wt \\
\hline Control & $39.0 \mathrm{a}^{\mathrm{z}}$ & $220.4 \mathrm{a}$ & $84.3 \mathrm{a}$ & $24.4 \mathrm{a}$ & $42.1 \mathrm{a}$ & $17.8 \mathrm{a}$ \\
\hline $\mathrm{K}$ & $30.4 \mathrm{a}$ & $126.4 \mathrm{~b}$ & $44.7 \mathrm{~b}$ & $15.7 \mathrm{a}$ & $20.4 \mathrm{ab}$ & $8.6 \mathrm{ab}$ \\
\hline $\mathrm{Mg}$ & $36.5 \mathrm{a}$ & $81.8 \mathrm{~b}$ & $28.7 \mathrm{~b}$ & $8.0 \mathrm{~b}$ & $14.4 \mathrm{~b}$ & $6.3 \mathrm{~b}$ \\
\hline $\mathrm{Ca}$ & $36.9 \mathrm{a}$ & $118.2 \mathrm{~b}$ & $45.9 \mathrm{~b}$ & $5.6 \mathrm{~b}$ & $29.1 \mathrm{a}$ & $11.2 \mathrm{a}$ \\
\hline
\end{tabular}

${ }^{\bar{z}}$ Mean separation within columns at $p=0.05$ by Duncan's multiple range test.

all experiments were subjected to analyses of variance and treatment means separated by Duncan's multiple range test (5\% level).

Biomass content. Plant leaves, shoots and roots were harvested from each plant after ten months growth period and weighed. Fresh plant material was oven-dried at $65^{\circ} \mathrm{C}$ for $72 \mathrm{~h}$ to determine organ dry weight.

Mineral analysis. Samples of $50 \mathrm{mg}$ leaf powder were extracted with $10 \mathrm{~mL}$ deionized water according to Bar-Akiva (1974). After 30 minutes of shaking, K, Mg and Ca were determined by atomic absorption spectroscopy and $\mathrm{P}$ by autoanalyzer.

Chlorophyll determination. Samples of $50 \mathrm{mg}$ fresh leaf tissue were extracted with $80 \%$ acetone, and their chlorophyll content determined according to Arnon (1949).

Total Nitrogen, NITRATES, FREE AMINo ACIDS, AND PROTEIN CONTENT. Excised leaves were washed, dried in a forced air oven at $65^{\circ} \mathrm{C}$ and ground with a Wiley mill to a 40 -mesh powder. Total nitrogen was determined in 200-mg samples of the dried leaf tissue which were subjected to acid digestion with $4.0 \mathrm{~mL}$ of concentrated $\mathrm{H}_{2} \mathrm{SO}_{4}$. During the digestion procedure the solution was cooled off three or four times and $1 \mathrm{~mL}$ of $30 \% \mathrm{H}_{2} \mathrm{O}_{2}$ was added. The samples were diluted to $100 \mathrm{~mL}$ with $\mathrm{H}_{2} \mathrm{O}$. Nitrogen content was determined according to Clare and Stevenson (1964).

Water extractable nitrates were prepared from $50 \mathrm{mg}$ dried leaf powder. Samples were shaken with $10 \mathrm{~mL} \mathrm{H}_{2} \mathrm{O}$ for $30 \mathrm{~min}$ and filtered through Whatman 40 filter paper (Bar-Akiva, 1974). The $\mathrm{N}-\mathrm{NO}_{3}$ value was determined by a method adopted for autoanalyzer procedure in which $\mathrm{NO}_{3}$ was reduced to $\mathrm{NO}_{2}$ by the aid of a cadmium column at $\mathrm{pH} 9.6$ and the nitrite formed was determined spectrophotometrically (Kamm et al., 1965; Shaked et al., 1972).

Samples for amino acid analysis were prepared according to Yemm and Cocking (1955). Free amino acids were extracted from a 100 -mg dried leaf powder with $80 \% \mathrm{EtOH}$ at $75^{\circ} \mathrm{C}$ and the extraction procedure was repeated four times. After centrifugation at $1,000 \mathrm{~g}_{\mathrm{n}}$ for $10 \mathrm{~min}$. An aliquot of the supernatant equivalent to $66.6 \mathrm{mg}$ dry weight was removed, evaporated to dryness and dissolved with 0.5 $\mathrm{mL} 100 \mathrm{~mm}$ citrate buffer and $2.2 \%$ thiodiethanol ( $\mathrm{pH} 2.2$ ). A 50- $\mu \mathrm{L}$ sample was injected into the amino acid analyzer.

Protein was extracted from $1 \mathrm{~g}$ fresh leaf material with $125 \mathrm{~mm}$ Tris-glycine buffer ( $\mathrm{pH} 8.3$ ) containing $3 \%$ insoluble PVP and the protein content was measured according to Bradford (1976).
ExTRACTION OF SOLUBLE AND CHLOROPLAST MEMBRANAL PROTEINS FOR SDS-PAGE. Chloroplast membrane proteins for the separation on SDS-PAGE were extracted in Hepes grinding medium and suspended in Hepes suspension medium as described previously (Lerer and Bar-Akiva, 1979). SDS-PAGE was carried out on $5 \%$ to $15 \%$ polyacrylamide gradients according to Laemmli (1970). Gels were stained with Coommassie blue R-250.

Nitrate REDUCTASE ACTIVITY. Enzyme activity was assayed in vivo (Shaked et al., 1972). For determination of the initial activity leaves were preincubated in $\mathrm{H}_{2} \mathrm{O}$, and for determination of the induced activity leaves were preincubated in $0.05 \mathrm{M} \mathrm{KNO}_{3}$. Preincubation was performed by immersing the leaf petioles in the above solutions for $2 \mathrm{~h}$ at room temperature. Nitrate reductase activity was assayed following incubation of $125 \mathrm{mg}$ leaf discs $(2.5$ $\mathrm{mm}$ in diameter) for $2 \mathrm{~h}$ in $30^{\circ} \mathrm{C}$ in darkness (Shaked et al., 1974). The incubation medium consisted of $2.0 \mathrm{~mL} 0.02 \mathrm{M} \mathrm{KNO}_{3}$ in 0.05 $\mathrm{M}$ Tris- $\mathrm{HCl}$ buffer ( $\mathrm{pH}$ 7.8). The reaction was stopped by adding 1 $\mathrm{mL}$ of $1 \%$ sulfanilamide and was followed by spectrophotometric measurement of the nitrite formed in the incubation medium (Shaked et al., 1972).

RubPcase ACTIVITY. Fully expanded fresh leaves excluding the midvein $(1 \mathrm{~g})$ were homogenized in $5 \mathrm{~mL}$ extraction buffer containing $100 \mathrm{~mm}$ Tris- $\mathrm{HCl}\left(\mathrm{pH} \mathrm{8.6)}, 20 \mathrm{~mm} \mathrm{MgCl}_{2}, 10 \mathrm{~mm}\right.$ $\mathrm{NaHCO}_{3}$, and $1.5 \mathrm{~mm}$ DTT in cold mortar and pestle. The homogenate was filtered through Miracloth and centrifuged for $30 \mathrm{~min}$ at $27,000 g_{\mathrm{n}}$ at $4{ }^{\circ} \mathrm{C}$. The supernatant was immediately used for detection of enzyme activity (Markus, et al., 1981). The 400- $\mu \mathrm{L}$ reaction buffer contained $100 \mathrm{~mm}$ Tris- $\mathrm{HCl}(\mathrm{pH} 8), 20 \mathrm{~mm} \mathrm{MgCl}$, and $50-\mu \mathrm{L}$ reaction mixture composed of $120 \mathrm{~mm} \mathrm{NaHCO}_{3}, 18.5$ $\mathrm{GBq} \mathrm{NaH}{ }^{14} \mathrm{CO}_{3}$ (specific activity $1.9 \mathrm{GBq} \cdot \mathrm{m}^{-1} \cdot \mathrm{mol}^{-1}$ ). After 10 min of preincubation at $30^{\circ} \mathrm{C}, 20 \mu \mathrm{L}$ of $20 \mathrm{~mm}$ RuBP was added followed by the addition of $50 \mu \mathrm{L}$ plant extract to start the reaction. The reaction was stopped after $120 \mathrm{~s}$ by the addition of $5 \%$ TCA. Excess of ${ }^{14} \mathrm{CO}_{2}$ was removed by a stream of compressed air, and after evaporation of the mixture to dryness, the radioactivity of acid-stable products was determined by a liquid scintillation spectrometer, in a scintillation solution containing $40 \%$ Lumax and $60 \%$ toluene. The results are means of three measurements

IMMUNOLOGICAL QUANTIFICATION OF RUBPCASE BY ELISA. Antibodies against the holoenzyme, LSU, and SSU from spinach were kindly

Table 2. Concentration of total $\mathrm{N}, \mathrm{NO}_{3}-\mathrm{N}(\mathrm{n}=6), \mathrm{P}, \mathrm{K}, \mathrm{Mg}$, and $\mathrm{Ca}(\mathrm{n}=12)$ in control and mineral-deficient rough-lemon leaves. Concentrations of $\mathrm{K}, \mathrm{Mg}$, and $\mathrm{Ca}$ in the respective deficiency treatments are underlined.

\begin{tabular}{|c|c|c|c|c|c|c|}
\hline Treatment & $\begin{array}{l}\mathrm{N} \\
(\%)\end{array}$ & $\begin{array}{l}\mathrm{NO}_{3}-\mathrm{N} \\
\left(\mu \mathrm{g} \cdot \mathrm{g}^{-1}\right)\end{array}$ & $\begin{array}{l}\mathrm{P} \\
(\%)\end{array}$ & $\begin{array}{c}\mathrm{K} \\
(\%)\end{array}$ & $\begin{array}{l}\mathrm{Mg} \\
(\%)\end{array}$ & $\begin{array}{l}\mathrm{Ca} \\
(\%)\end{array}$ \\
\hline Control & $2.68 \mathrm{a}^{\mathrm{z}}$ & $867.5 \mathrm{a}$ & $0.098 \mathrm{~b}$ & $1.54 \mathrm{~b}$ & $0.30 \mathrm{c}$ & $0.52 \mathrm{~b}$ \\
\hline K & $2.96 \mathrm{a}$ & $227.6 \mathrm{~b}$ & $0.119 \mathrm{ab}$ & $\underline{0.78 \mathrm{c}}$ & $0.44 \mathrm{~b}$ & $1.01 \mathrm{a}$ \\
\hline $\mathrm{Mg}$ & $2.64 \mathrm{a}$ & $302.8 \mathrm{~b}$ & $0.117 \mathrm{~b}$ & $\overline{2.08 \mathrm{a}}$ & $\underline{0.15 \mathrm{~d}}$ & $0.32 \mathrm{c}$ \\
\hline $\mathrm{Ca}$ & $1.99 \mathrm{~b}$ & $115.5 \mathrm{c}$ & $0.146 \mathrm{a}$ & $1.35 \mathrm{~b}$ & $\overline{0.76 \mathrm{a}}$ & $\underline{0.21 \mathrm{c}}$ \\
\hline
\end{tabular}

${ }^{\mathrm{z}}$ Mean separation within columns at $p=0.05$ by Duncan's multiple range test. 
provided by S. Gepstein, Israel Institute of Technology, Haifa. Crossreactivity was found between these antibodies and the corresponding polypeptides of citrus (Lavon, 1992). RuBPcase extracts were prepared from fresh leaves homogenized in $20 \mathrm{~mm}$ phosphate buffer $(\mathrm{pH}$ 7.4) containing $0.15 \mathrm{M} \mathrm{NaCl}, 0.05 \%$ Tween-20 and $2 \%$ soluble PVP (in PBS buffer). Antigen coated ELISA plates were prepared according to Clark and Adams (1977) and Joisson et al. (1992). Wells of ELISA plates were covered with $200 \mu \mathrm{L}$ RuBPcase extracts diluted to suitable concentrations with $15 \mathrm{~mm} \mathrm{Na}_{2} \mathrm{CO}_{3}, 35 \mathrm{~mm} \mathrm{Na}_{2} \mathrm{HCO}_{3}(\mathrm{pH}$ 9.6) containing $0.02 \% \mathrm{Na}$ azide (fixation buffer). Plates were incubated overnight at $5^{\circ} \mathrm{C}$ and then washed with distilled water followed by three washings with PBS buffer containing $0.05 \%$ Tween- 20 . Amounts of $200 \mu \mathrm{L}$ holoenzyme antiserum diluted 1000 times or LSU and SSU antiserum diluted 500 times with PBS buffer containing $2 \%$ soluble PVP and $0.2 \%$ BSA, were added to each well. After incubation for $60 \mathrm{~min}$ at $37^{\circ} \mathrm{C}$ the plates were washed with PBS buffer, and $200 \mu \mathrm{L}$ of phosphatase-conjugate anti rabbit IgG diluted 1000 times were added to each well. The plates were incubated for 3 h at $37^{\circ} \mathrm{C}$, washed, and color was finally developed by adding $200 \mu \mathrm{L}$ of p-nitrophenylphosphate. After incubation for $15 \mathrm{~min}$ at $37^{\circ} \mathrm{C}$ the absorbance was measured at $405 \mathrm{~nm}$. Controls without serum or phosphatase-conjugate were used as blanks and showed very low absorbance.

\section{Results}

Biomass accumulation. Plants grown under $\mathrm{K}-, \mathrm{Mg}-$, and $\mathrm{Ca}-$ deficient conditions produced significantly less biomass (Table 1) but dry weight percentage and the root to shoot ratio were not affected. Leaf size was reduced in the K deficiency treatment and leaf drop occurred in the $\mathrm{Mg}$ and $\mathrm{Ca}$ deficiencies.

Mineral Concentration. In full nutrient solutions the concentrations of $\mathrm{K}, \mathrm{Mg}$ and $\mathrm{Ca}$ were in the optimum high range (Embleton et al., 1973). When grown in mineral-deficient solutions, tissue concentrations of these minerals were significantly reduced. Total $\mathrm{N}$ concentrations in $\mathrm{K}$ - and $\mathrm{Mg}$-deficient leaves were similar to those of control leaves, but $\mathrm{Ca}$-deficient leaves had a significantly lower $\mathrm{N}$ content (Table 2). Levels of $\mathrm{NO}_{3}-\mathrm{N}$ appeared to be much more sensitive to nutritional disorders than total N. Leaf nitrates were significantly lower in all the deficiency treatments; particularly so in the Ca-deficient leaves (Table 2).

Chlorophyll concentrations. Potassium-deficient leaves did not develop chlorosis, and their chlorophyll concentration was similar to that of control leaves. Chlorophyll levels were significantly reduced under $\mathrm{Mg}$ deficiency and reduced even further in $\mathrm{Ca}$ deficient leaves which developed the typical chlorosis symptoms (Table 3 ). The chlorophyll a/b ratio was not significantly altered, however, by any of the mineral deficiency treatments (Table 3).

CONCENTRATIONS OF SOLUBLE PROTEIN AND FREE AMINO ACIDS. The total concentration of free amino acids was $30 \%$ higher in $\mathrm{K}$ deficient than in control leaves with a significant accumulation of arginine, lysine, and histidine (Table 4). These acids which comprised $5.52 \%$ of the total amino acids in the control increased to $31.2 \%$ in K-deficient leaves. The concentration of free amino acids in $\mathrm{Mg}$-deficient leaves was similar to that in the controls, except for a slight increase in arginine (Table 4). In Ca-deficient leaves, total free amino acids content was drastically reduced to $32 \%$ of the control. The most striking decrease occurred in proline which was reduced 6-fold (Table 4).

Soluble protein levels were not affected by the nutritional disorders resulting from treatments employed in this study (Table 3).

Nitrate Reductase activity. The initial in vivo activity of nitrate reductase was lower in all the deficient treatments but significantly so only in Ca-deficient leaves (Table 5). Incubation of the mineral-deficient leaves with $\mathrm{KNO}_{3}$ restored nitrate reductase activity to the normal, control levels.

RUBPCASE ACTIVITY AND RUBPCASE PROTEIN LEVEL. RuBPcase activity was somewhat lower in $\mathrm{K}$ - and Mg-deficient leaves but substantially lower in Ca-deficient leaves (Table 6). There were no significant changes in RuBPcase activity on a chlorophyll basis (Table 6).

The concentration of RuBPcase protein from $\mathrm{K}$ - and $\mathrm{Mg}$ deficient leaves, as observed on SDS-PAGE was similar to that of

Table 3. Soluble protein $(n=8)$, and chlorophyll $(n=16)$, levels, in control, $\mathrm{K}-, \mathrm{Mg}-$, and $\mathrm{Ca}-\mathrm{deficient}$ rough-lemon leaves.

\begin{tabular}{llcc}
\hline \hline & \multicolumn{3}{c}{$\begin{array}{c}\text { Foliar concn (fresh wt basis) } \\
\left(\mathrm{mg} \cdot \mathrm{g}^{-1}\right)\end{array}$} \\
\cline { 2 - 4 } & $\begin{array}{l}\text { Soluble } \\
\text { protein }\end{array}$ & $\begin{array}{c}\text { Chlorophyll } \\
\mathrm{a}+\mathrm{b}\end{array}$ & $\begin{array}{c}\text { Chlorophyll } \\
\mathrm{a} / \mathrm{b}\end{array}$ \\
\hline Control & $12.8 \mathrm{ab}^{\mathrm{z}}$ & $1.98 \mathrm{a}$ & $2.16 \mathrm{bc}$ \\
$\mathrm{K}$ & $14.8 \mathrm{a}$ & $2.15 \mathrm{a}$ & $1.97 \mathrm{c}$ \\
$\mathrm{Mg}$ & $13.5 \mathrm{ab}$ & $1.12 \mathrm{~b}$ & $2.41 \mathrm{a}$ \\
$\mathrm{Ca}$ & $10.4 \mathrm{~b}$ & $0.78 \mathrm{c}$ & $2.22 \mathrm{ab}$ \\
\hline
\end{tabular}

${ }^{\mathrm{z}}$ Mean separation within columns at $p=0.05$ by Duncan's multiple range test.

Table 4. The effect of mineral deficiencies on free amino acids in control, $\mathrm{K}, \mathrm{Mg}$ and Ca-deficient rough-lemon leaves $(\mathrm{n}=6)$

\begin{tabular}{lcccc}
\hline \multirow{2}{*}{ Amino } & \multicolumn{4}{c}{$\begin{array}{c}\text { Amino acids concn (dry wt basis) } \\
\left(\mathrm{nmol} \cdot \mathrm{mg}^{-1}\right)\end{array}$} \\
\cline { 2 - 5 } acid & Control & $\mathrm{K}$ & $\mathrm{Mg}$ & $\mathrm{Ca}$ \\
\hline Asp & 0.79 & 0.80 & 0.96 & 0.48 \\
Thr & 0.26 & 0.38 & 0.41 & 0.54 \\
Ser & $1.15 \mathrm{a}^{\mathrm{z}}$ & $0.42 \mathrm{~b}$ & $1.11 \mathrm{a}$ & $1.33 \mathrm{a}$ \\
Glu & $12.65 \mathrm{ab}$ & $17.40 \mathrm{a}$ & $12.62 \mathrm{ab}$ & $3.95 \mathrm{~b}$ \\
Pro & $73.67 \mathrm{a}$ & $63.00 \mathrm{a}$ & $62.26 \mathrm{a}$ & $12.92 \mathrm{~b}$ \\
Gly & $1.91 \mathrm{a}$ & $2.02 \mathrm{a}$ & $1.41 \mathrm{ab}$ & $0.70 \mathrm{~b}$ \\
Ala & 9.16 & 8.98 & 8.25 & 5.62 \\
Cys/2 & 0.19 & 0.18 & 0.27 & 0.14 \\
Val & 1.84 & 2.11 & 1.53 & 1.15 \\
Met & 0.41 & 0.14 & 0.17 & 0.24 \\
Ile & 0.92 & 0.93 & 0.72 & 0.67 \\
Leu & 1.86 & 2.31 & 1.55 & 1.69 \\
Tyr & 1.05 & 1.06 & 1.05 & 0.65 \\
Phe & 0.76 & 1.07 & 0.99 & 0.38 \\
His & $3.81 \mathrm{~b}$ & $11.20 \mathrm{a}$ & $4.80 \mathrm{~b}$ & $3.99 \mathrm{~b}$ \\
Lys & $0.57 \mathrm{~b}$ & $13.91 \mathrm{a}$ & $0.66 \mathrm{~b}$ & $0.35 \mathrm{~b}$ \\
Arg & $1.85 \mathrm{~b}$ & $20.68 \mathrm{a}$ & $5.32 \mathrm{~b}$ & $0.95 \mathrm{~b}$ \\
Total acids & $112.85 \mathrm{ab}$ & $146.59 \mathrm{~b}$ & $103.58 \mathrm{~b}$ & $35.75 \mathrm{c}$ \\
\hline
\end{tabular}

${ }_{\mathrm{Z}}$ Different letters within rows indicate significance at $p=0.05$ level by Duncan's multiple range test.

Table 5. Initial and Induced nitrate reductase activity in control, $\mathrm{K}, \mathrm{Mg}$ and $\mathrm{Ca}$ deficient rough-lemon leaf discs $(n=6)$.

\begin{tabular}{llcc}
\hline \hline & \multicolumn{3}{c}{$\begin{array}{c}\text { Nitrate reductase activity }\left(\mathrm{NO}_{2}, \text { fresh wt basis }\right) \\
\left(\mathrm{nmol} \cdot \mathrm{g}^{-1} \cdot \mathrm{h}^{-1}\right)\end{array}$} \\
\cline { 2 - 4 } & $\begin{array}{c}\text { Initial } \\
\text { Treatment }\end{array}$ & $\begin{array}{c}\text { Induced } \\
\text { activity }\end{array}$ & $\begin{array}{c}\text { Induced/Initial } \\
\text { ratio }\end{array}$ \\
\hline Control & $468 \mathrm{a}^{\mathrm{z}}$ & $502 \mathrm{a}$ & $1.11 \mathrm{c}$ \\
$\mathrm{K}$ & $242 \mathrm{ab}$ & $491 \mathrm{a}$ & $1.98 \mathrm{~b}$ \\
$\mathrm{Mg}$ & $299 \mathrm{ab}$ & $625 \mathrm{a}$ & $2.36 \mathrm{~b}$ \\
$\mathrm{Ca}$ & $191 \mathrm{~b}$ & $698 \mathrm{a}$ & $3.76 \mathrm{a}$
\end{tabular}

${ }^{\mathrm{Z}}$ Mean separation within columns at $p=0.05$ by Duncan's multiple range test. 
Table 6. RuBPcase activity in control, $\mathrm{K}, \mathrm{Mg}$ and $\mathrm{Ca}$-deficient roughlemon leaf extracts $(n=8)$.

\begin{tabular}{lccc}
\hline & \multicolumn{3}{c}{$\begin{array}{c}\text { RuBPcase activity }\left(\mathrm{CO}_{2} \text { fixed }\right) \\
\left(\mathrm{nmol} \cdot \mathrm{min}^{-1}\right)\end{array}$} \\
\cline { 2 - 4 } Treatment & $\left(\mathrm{mmol} \cdot \mathrm{mg}^{-1} \cdot \mathrm{min}^{-1}\right)$ & $(\mathrm{mg})$ & $\left(\mathrm{mmol} \cdot \mathrm{mg}^{-1} \cdot \mathrm{min}^{-1}\right)$ \\
\hline Control & $436 \mathrm{a}^{\mathrm{z}}$ & $5120 \mathrm{a}$ & $2555 \mathrm{a}$ \\
$\mathrm{K}$ & $351 \mathrm{~b}$ & $4694 \mathrm{a}$ & $2641 \mathrm{a}$ \\
$\mathrm{Mg}$ & $380 \mathrm{ab}$ & $4520 \mathrm{a}$ & $2484 \mathrm{a}$ \\
$\mathrm{Ca}$ & $278 \mathrm{c}$ & $2596 \mathrm{~b}$ & $2113 \mathrm{a}$
\end{tabular}

${ }^{\mathrm{z}}$ Mean separation within columns at $p=0.05$ by Duncan's multiple range test.

the controls but in Ca-deficient leaves it was substantially reduced (Fig. 1). The level of RuBPcase holoenzyme was significantly lower in Ca-deficient leaves, as revealed by ELISA; there was a decline of $65 \%$ in the small subunit (SSU) and of $29 \%$ in the large subunit (LSU) (Fig. 2). The SDS-PAGE profile of leaf soluble proteins indicated that most protein bands were fainter in $\mathrm{Ca}$ deficient leaf extracts (Fig. 1). However the intensity of 23- and 32$\mathrm{kDa}$ polypeptide bands increased in Ca-deficient leaves and a novel 12-kDa polypeptide became apparent (Fig. 1). Band intensity of the 34- and 35-kDa polypeptides increased somewhat in Kdeficient extracts (Fig. 1).

There were no prominent qualitative differences in chloroplast membranal protein components between the deficient treatments and the control as seen on SDS-PAGE, but the intensity of the bands from Ca-deficient leaves was generally weaker than that of other treatments (Fig. 3).

\section{Discussion}

The present study is part of an investigation into the metabolic disturbances associated with $\mathrm{K}, \mathrm{Mg}$, and Ca deficiencies in citrus. In an earlier report (Lavon et al., 1995) we described some K deficiency-induced changes in the carbohydrate metabolism. In the present article we examined the relationship between $\mathrm{K}, \mathrm{Mg}$, and $\mathrm{Ca}$ deficiency-induced changes in nitrogenous constituents and leaf chlorosis. Potassium-deficient plants produced less biomass and revealed some changes in nitrogen metabolism (Tables 2 , 4 , and 5) but did not develop leaf chlorosis (Table 3).

Magnesium deficiency resulted in loss of chlorophyll (Table 3) and typical leaf chlorosis symptoms. The effects on nitrogen metabolism were confined, however, to a reduction in nitrate concentrations (Table 2), which brought about a partial impairment of the nitrate reductase system (Table 5).

Calcium deficiency was the only treatment that revealed profound effects on the nitrogen economy of citrus leaves. Calciumdeficient leaves had lower total nitrogen levels and a markedly reduced nitrate concentration (Table 2). The interference of $\mathrm{Ca}$ deficiency with nitrogen metabolism was also reflected in the extreme reduction of the free amino acid pool (Table 4). Proline, the most abundant free amino acid in citrus (Kato, 1986), and glutamic acid, a precursor of proline synthesis and the amino groups of most amino acids (Stewart, 1961), were most severely affected. On the other hand, there was only a minor, nonsignificant change in the protein level of Ca-deficient leaves (Table 3) which may have been caused by the decline in the level of RuBPcase (Fig. 2).

The 12-kDa polypeptide that appeared in the soluble protein fraction of Ca-deficient leaves (Fig. 1) might be related to Starvation Induced Proteins (SIP) which have been reported to occur in plants under stress conditions (Nover, 1989).

Nitrate reductase initial activity was severely reduced under $\mathrm{Ca}$ deficiency (Table 5), presumably due to the shortage of substrate
(Shaked et al., 1974). Inhibition of nitrate reductase activity under Ca deficiency was also described by Matsumoto et al. (1980) in cucumber cotyledons. The data of the present study suggests that $\mathrm{Ca}$ deficiency leads to a severe shortage of nitrate, thereby causing a major metabolic disturbance. It is impossible at the present time to identify the metabolic reaction, which is the source of this disturbance

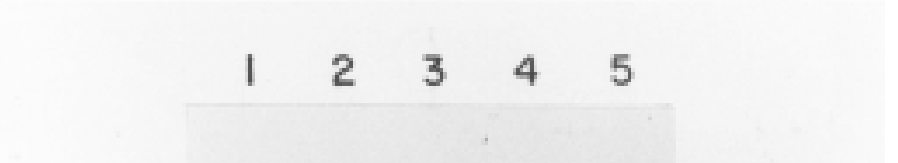

Fig. 1. Soluble protein pattern of rough-lemon leaf extracts from different nutritional treatments separated on SDS-PAGE. Lane $1=$ molecular mass markers. Lane 2 $=\mathrm{K}$-deficient leaf. Lane $3=\mathrm{Mg}$-deficient leaf. Lane $4=\mathrm{Ca}$-deficient leaf. Lane $5=$ control leaf. Each lane was loaded with $35 \mu \mathrm{g}$ protein.

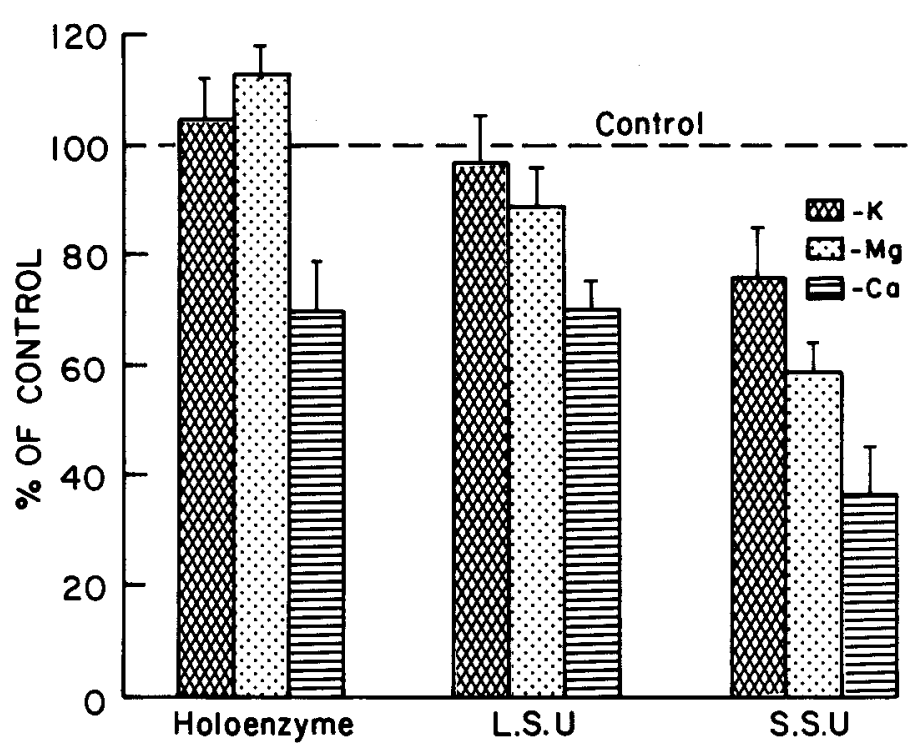

Fig. 2. Changes of RuBPcase in rough-lemon leaves from different nutritional treatments. The levels of RuBPcase were quantified by ELISA and the changes are represented as percent of control. Wells of ELISA plates were filled with leaf extracts $(4 \mu \mathrm{g}$ fresh weight per well) and incubated with native RuBPcase antiserum diluted 1:1000 for the holoenzyme and denatured LSU or SSU antiserums diluted 1:500 for each subunit. Each column is the mean $\pm \mathrm{SE}$ of five experiments. 


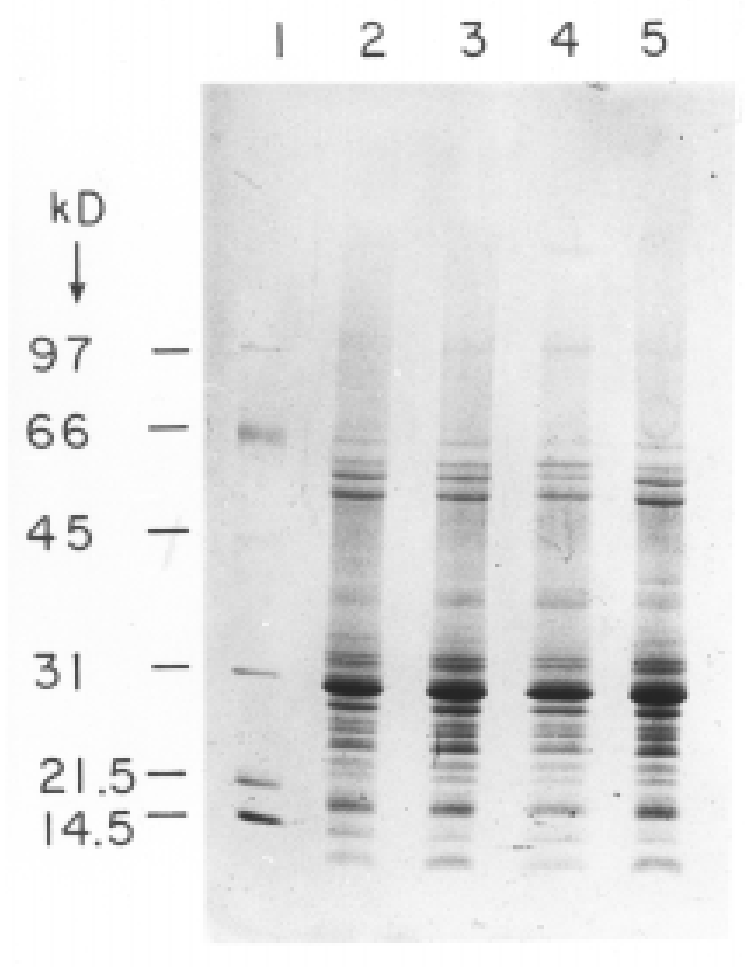

Fig. 3. Pattern of chloroplast membranal proteins of rough-lemon leaves from different nutritional treatments separated on SDS-PAGE. Lane 1. Molecular mass markers. Lane $2=\mathrm{K}$-deficient leaf. Lane $3=\mathrm{Mg}$-deficient leaf. Lane $4=\mathrm{Ca}$ deficient leaf. Lane $5=$ control leaf. Each lane was loaded with $5 \mu \mathrm{g}$ protein.

but the nitrate uptake step appears as a likely candidate.

This, hitherto largely unnoticed link between Ca deficiency and nitrogen metabolism is by all probability not confined to citrus and should be investigated in other systems.

Both $\mathrm{Mg}$ and $\mathrm{Ca}$ deficiencies resulted in leaf chlorosis and a significant decline in chlorophyll levels. Nevertheless, soluble protein concentrations did not reveal a significant decline (Table 3). Furthermore, SDS-PAGE of soluble proteins (Fig. 1) did not disclose major differences between mineral-deficient leaves and controls. Similarly, the retention of all major chlorophyll membrane protein components (Fig. 3) and the maintenance of nearly normal chlorophyll $\mathrm{a} / \mathrm{b}$ ratios (Table 3 ) indicates a lack of major obstruction of the photosynthetic apparatus. All this suggests the existence of an effective homeostatic mechanism, which protects and maintains the plant's metabolic integrity and ensures its continued function even under adverse nutritional conditions, at least within the time frame of our experiments.

All in all, the data presented do not fully support our initial assumption. The chlorotic leaves of Mg-deficient citrus plants did not reveal major changes in nitrogen status, indicating that leaf chlorosis is not necessarily linked with changes in nitrogen metabolism. Ca deficiency appears to be a special case in which leaf chlorosis indeed reflects a broader interference involving farreaching alterations of nitrogen metabolism.

\section{Literature Cited}

Arnon, D.I. 1949. Copper enzymes in isolated chloroplasts, polyphenol-oxidase in Beta vulgaris. Plant Physiol. 24:1-15.

Bar-Akiva, A. 1974. Nitrate estimation in Citrus leaves as a means of evaluating nitrogen fertilizer requirement of citrus trees. Proc. Intl. Citrus Congr. Murcia 1:159-164.

Bradford, M. 1976. A rapid and sensitive method for the quantitation of microgram quantities of protein utilizing the principle of protein dye binding. Anal. Biochem. 72:248-250.

Chapman, H.D. 1968. Mineral nutrition of citrus, p. 127-189. In: W. Reuther, L.D.
Batchelor, and H.J. Webber (eds.). The citrus industry. Revised ed. vol. 2. Univ. Calif. Div. Agr. Sci., Berkeley.

Clare, N.T. and A. Stevenson. 1964. Measurement of feed nitrogen of grazing cattle and sheep. I. Determination of nitrogen in feces and feed using autoanalyser. N.Z. J. Agr. Res. 7:198-204.

Clark, M.F. and A.N. Adams. 1977. Characteristics of the microplate method of enzymelinked immunosorbent assay for the detection of plant viruses. J. Gen. Virol. 34: 475483.

Durzan, D.J. 1995. Free amino acids as indicators of little leaf in zinc deficiency in the pistachio (Pistacia vera L. cultivar 'Kerman' ). Scientia Hort. 60:221-233.

Embleton, T.W., H.J. Reitz, and W.W. Jones. 1973. Citrus fertilization, p. 122-182. In: W. Reuther (ed.). The citrus industry. Revised ed. vol. 3. Univ. Calif. Div. Agr. Sci., Berkeley.

Evans, J.R. and J.R. Seeman. 1989. The allocation of protein nitrogen in the photosynthetic apparatus: Costs, consequences and control, p. 183-205 In: W.R. Briggs (ed.). Photosynthesis. Plant biology. vol. 8. Alan R. Liss, New York.

Hecht-Buchholz, C. 1979. Calcium deficiency and plant ultrastructure. Commun. Soil Sci. Plant Anal. 10:67-81.

Kamm, L., G.G. Mckeown, and D. Morison Smith. 1965. A new colorimetric method for the determination of nitrate content of baby foods. J. Assn. Agr. Chem. 48:892-895

Joisson, C., M.C. Dubes, J. Briand, and M. van Regenmortel. 1992. Detection of potyviruses with antisera to synthetic peptides. Res. Virol. 143:167-178.

Kamm, L., G.G. Mckeown, and D. Morison Smith. 1965. A new colorimetric method for the determination of nitrate content of baby foods. J. Assn. Agr. Chem. 48:892-895.

Kato, T. 1986. Nitrogen metabolism and utilization in Citrus. Hort. Rev. 8:181-216.

Laemmli, U.K. 1970. Cleavage of structural proteins during the assembly of the food of bacteriophage T4. Nature (London) 227:680-685.

Lavon, R. 1992. The effect of calcium, magnesium and potassium deficiencies on metabolism and development of Citrus plants. PhD diss. Hebrew Univ. of Jerusalem, Israel.

Lavon, R., E.E. Goldschmidt, R. Salomon, and A. Frank. 1995. Effect of potassium, magnesium, and calcium deficiencies on carbohydrate pools and metabolism in citrus leaves. J. Amer. Soc. Hort. Sci. 120:54-58.

Lawlor, D.W. 1994. Relation between carbon and nitrogen assimilation, tissue composition and whole plant function, p. 47-60. In: Roy J. and E. Garnier (eds.). A whole plant perspective on carbon-nitrogen interactions, SPB Academic Publishing Co., The Hague, The Netherlands.

Lawlor, D.W., F.A. Boyle, A.C. Kendall, and A.J. Keys. 1987. Nitrate nutrition and temperature effects on wheat: Enzyme composition, nitrate and total amino acids content of leaves. J. Expt. Bot. 38:378-392.

Lerer, M. and A. Bar-Akiva. 1979. Effect of manganese deficiency on chloroplasts of lemon leaves. Physiol. Plant. 47:163-166.

Markus, V., S. Lurie, B. Bravdo, M.A. Stevens, and J. Rudich. 1981. high temperature effects on RuBP carboxylase and carbonic anhydrase activity in two tomato cultivars. Physiol. Plant. 53:407-412.

Matsumoto, H., K. Teraoka, and T. Kawasaki. 1980. Repression of nitrate reductase in cucumber leaves caused by calcium deficiency. Plant Cell Physiol. 21:183-191.

Nover, L. 1989. Other plant stress response systems, p. 78-99. In: L. Nover, D. Neuman, and K.D. Schaf (eds.). Heat shock and other stress response systems of plants. SpringerVelag, Berlin, Germany.

Osaki, M., K. Morikawa, M. Matsumoto, T. Shinano, M. Iyoda, and T. Tadano. 1993. Productivity of high yielding crops. III. Accumulation of ribulose-1,5-bisphosphate carboxylase/oxygenase and chlorophyll in relation to productivity of high yielding crops. Soil Sci. Plant Nutr. 39:399-408.

Peoples, T.R. and D.W. Koch. 1979. Role of potassium in carbon dioxide assimilation in Medicago sativa L. Plant Physiol. 63:878-881.

Rabe, E. and C.J. Lovatt. 1984. De novo arginine biosynthesis in leaves of phosphorusdeficient Citrus and Poncirus species. Plant Physiol. 76:747-752.

Rabe, E. 1990. Stress physiology: The functional significance of the accumulation of nitrogen-containing compounds. J. Hort. Sci. 65:231-243.

Shaked, A., A. Bar-Akiva, and K. Mendel. 1972. Effect of water stress and high temperature on nitrate reduction in citrus leaves. J. Hort. Sci. 47:183-190.

Shaked A., A. Bar-Akiva, and K. Mendel 1974. Nitrate reductase activity as an indication of the nitrogen status and requirement of citrus trees under orchard conditions, p. 165170. In: Proc. Intl. Citricult. Congr., Murcia Spain. vol. 1.

Smith, P.F. 1966. Citrus nutrition, p. 174-207. In: F. Norman (ed.). Nutrition of fruit crops. Tropical, subtropical, temperate tree and small fruits. Hort. Publ., Rutgers State Univ., New Brunswick, N.J.

Stewart, I. 1961. Nitrogen transformations in citrus trees. Proc. Soil Crop Sci. Soc. Fla. 21:272-282.

Thomson, W.W. and T.E. Weier. 1962. The fine structure of chloroplasts from mineraldeficient leaves of Phaseolus vulgaris. Amer. J. Bot. 49:1047-1055.

Vesk, M., J.V. Possingham, and E.V. Mercer. 1966. The effect of mineral nutrient deficiencies on the structure of the leaf cells of tomato, spinach and maize. Austral. J. Bot. 14:1-8.

Yemm, E.W. and E.C. Cocking. 1955. The determination of amino acids with ninhydrin. Analyst 80:209-214. 